\title{
Relationship between Banker and Customer
}

\author{
Kuldeep Singh \\ LL.M student, Chandigarh University, Gharuan, Punjab, India
}

\begin{abstract}
How to cite this paper: Kuldeep Singh "Relationship between Banker and Customer" Published in International Journal of Trend in Scientific Research and Development (ijtsrd), ISSN: 24566470, Volume-3 | Issue-3, April 2019, pp.1535-1537, URL: https://www.ijtsrd.c om/papers/ijtsrd23

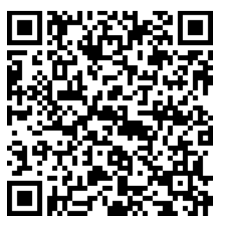
IITSRD23441
\end{abstract} 441.pdf

Copyright (C) 2019 by author(s) and International Journal of Trend in Scientific Research and Development Journal. This is an Open Access article distributed under the terms of the Creative Commons

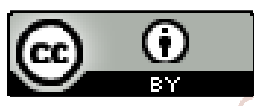
Attribution License (CC BY 4.0) (http://creativecommons.org/licenses/ by/4.0)

\section{ABSTRACT}

Customers are those who avail a service of any goods and services provided by the manufacturer or service provider with due consideration of money. In the same way the moment an individual opens an account with the banker, then he becomes a customer of the bank. Then there exists a special relationship of different duties and obligations between customer and banker. In view of the various services offered by a banker these days to his customers, the relationship between a banker and customer could be of various types . for instance, when a customer leaves some articles in safe custody with the bank, the relationship is one of the bailor and bailee. On another occasion when the banker collect collects a cheque for his customer and pays money on his behalf , the relationship is of principal and agent, It means banker must do their job very efficiently, while providing these services to the customer for the purpose of any transaction. In the same way in a relationship of of debtor and creditor, when the customer took a loan/advances from the bank then the banker will creditor and customer will debtor. Then it imposes a special duty/obligation cast upon the customer(debtor) to pay the instalments at proper time, there should be no delay for paying the instalments to discharge the loan amount. Due to these reasons both the banker and customer, after enter into in this relationship they bound to each and every condition with regard to their obligations and duties. Otherwise they can avail the legal remedy against each other for any of kind breach between them. To understand more clearly about this relationships, It is important to know who is a banker and who is a customer.

In this research paper researcher research that about the meaning and definitions of the banker and customer, and also about the different relations between them with duties and obligation against each other.

\section{KEYWORDS: - Banker, Customer, Banking, Relationship, Legal}

\section{INTRODUCTION}

Relation between banker and customer is consensual depending on express or implied contract between two. Thereby a contractual relation springs between banker and customer. In case of banking where a person asks the banker to open an account for him and the bankers acceptance thereof, constitutes implied contract of relationship.

The main banking function was and is to keep in custody other people money and lending a part of it. Gradually, these functions were extended, and new other were added. As a result the dependence of commerce upon banking has become so great that in modern money economy, the cessation, even for a day or two, of the bankers activity, would completely paralyse, the economic life of a nation. It will be proper to say that banking system has assumed the blood vessel of the economy of the country. Now-a-days the banker have to deal with a large of maters.

Relation of banker and customer depends upon the service given by the banker. In addition to his primary functions, a banker renders a number of services to his customer. The relationship between them primarily is that of a creditor and debtor. A banker also act as an agent or trustee of his customer if the latter entrusts the former with agency or trust work. In such cases, the banker act as a debtor, an agent and a trustee simultaneously but in relation to the specified business. ${ }^{1}$

\section{DEFINITION}

\section{BANK OR BANKER}

According to the provision of sections 5(b) and 5(c) of the Banking Regulation Act 1949 as to banking and banking company respectively. Common approach of bank is banking business and whosoever does banking business is a bank or banker. $^{2}$

The RBI- defines a modern bank

"An establishmnent for the custody of money received from or on behalf of its customer. It is essential duty is to pay their drafts on it, its profit arise from the use of the money left unemployement by them." Banks organize the borrowing and lemding work (credit) of the community, they lend their funds (capital) and borrowed funds and their own credit to person engaged in trade, agriculture, manufacturing and

${ }^{1}$ R.N.Choudhary,Banking Laws, central Law Publications, Allahabad, p-117-118.)

2 Ibid2,p-112 
other industries. They supply the part of the medium of exchange in the form of bank notes, cheques. ${ }^{3}$

\section{CUSTOMER}

According to Dr. Hart, "a customer is one who has an account with a banker or for whom banker habitually undertakes to act as such." Supporting tis view point, the kerela high court also observed in the case of central Bank of India ltd. Bombay v. V. Gopinathan Nair.

"Broadly speaking, a customer is a person who has the habit of resorting to the same place or person to do business. So far as banking transaction are concerned he is a person whose money has been accepted on the footing that banker will honour up to the amount standing to his credit, irrespective of his connection being of short or long standing."

For the purpose of KYC policy, a customer, is defined as :

1. a person or entity that maintains an account and/or has a business relationship with the bank.

2. one on whose behalf the account is maintained (i.e. the beneficial owner);

3. beneficiaries of transaction conducted by professional intermediaries, such as stock brokers, charted accountant, Solicitors etc. as permitted under the law, and

4. any person or entity connected with a financial transaction which can posses significant reputational or other risks to the bank, say, a wire transfer or issue of high value demand draft as a single transaction.

One may conclude that a "Customer" is one who has either a current or a deposit account or, in the absence of it, some relation with the bank in the ordinary course of business, that can be seen as banking business. ${ }^{4}$

RELATIONSHIP BETWEEN BANKER AND CUSTOMER

The general relationship between banker and customer is that of debtor and creditor. Sometimes, the banker act as agent, trustee or others also.

Relationship as debtor and creditor : The moment the customer opens an account with the banker, he becomes debtor of the customer and the customer becomes his creditor. The banker is then bound to return an equivalent amount of money, by paying a similar sum to the depositor when he is asked for it. In the same way banker also the creditor when any of the customer take the loan and any kind of advances from the bank then the customer is the debtor and the banker is creditor. Then customer(debtor) is bound to pay the loan amount to the banker(creditor) on the prescribed period of time. ${ }^{5}$

\section{Trustees and Beneficiary}

Banker as a trustee and Customer as a beneficiary

Ordinarily, a banker is a debtor of his customer in respect of the deposits made by the latter, but in certain circumstances he acts as a trustee also. A trustee holds money or assets and

\footnotetext{
${ }^{3}$ Reserve Bank of India.

${ }^{4}$ Vinod Kothari, Banking Law and Practice In India, 26 edition(Publication by Lexis Nexis),p-327-328.

${ }^{5}$ Jyotsna Sethi and Nishwan Bhatia, Elements of Banking and Insurance,(Published by PHI Learning Pvt. Ltd.

Delhi4.Reserve Bank of India.), p- 12.
}

performs certain functions for the benefit of some other person called the beneficiary. For example, if the customer deposit securities or valuables with the banker for safe custody, the latter act as a trustee of his customers.

The customer continues to be the owner of the valuable deposited with the banker. The legal position of the banker as a trustee, therefore, differs from that of a debtor of his customer. In the former case the money or documents held by him are not treated as his own and are not available for distribution amongst his general creditors in case of liquidation. ${ }^{6}$

\section{Agent and Principle}

Banker as an agent and Customer as an principle

A banker acts an agent of his customer in many ways, e.g., When he buys or sells securities or makes payment of vrious dues of his customers, or collects cheques on his behalf. In all these caes, the banker acts an agent of his customer. ${ }^{7}$

\section{BAILOR AND BAILEE}

\section{Banker as bailee and customer as bailor}

In addition to the above mentioned relations, there lao exists the relationship of bailment netween the Banker and the customer. Safe custody facility is one of the numerous facilities provided by commercial banks. In this case, the legal relationship of bailment arises between the customer and the banker, whereby customer depositing with thw bank is the bailor and the bank acts as the bailee. In case, where the bank does not charge any fees for such a purpose, the bank can be termed as a gratuitous bailee. In case, where a fee is charged, the bank becomes the bailee for reward.

Where bank offers safe custody facility to the customer, it takes a charge of goods, articles, seccurities, belonging to the customer, as a bailee and not as a trustee or an agent. ${ }^{8}$

There are other relationships also between them like

$>$ Mortgager and mortgagee.

$>$ Pledger and pledgee.

Hypothecator and hypothicatee.

$>$ Lessor and lessee.

\section{SPECIAL FEATURES OF RELATIONSHIP BETWEEN BANKER AND CUSTOMER}

\section{Statutory obligation on banks in india}

By opening an account, saving, term deposit accounts of a customer or rendering other services to the customers, the banker has some statutory duites and obligations.

1. Obligation to honour cheques having sufficient funds.

2. Liability to return the dishonour cheques to the customer.

Duty of banker to act as per the directons : The banker is bound to act according to direction given by the customer. In the absence of such directions, according to the usage in the locality and applicable to the matter in the hand, the banker

\footnotetext{
${ }^{6}$ R.N.Choudhary,Banking Laws, Published by Central Law Publications, Allahabad,p-124.

${ }^{7}$ Jyotsna Sethi and Nishwan Bhatia, Elements of Banking and Insurance,(Published by PHI Learning Pvt. Ltd.

Delhi,p-13.

${ }^{8}$ Vinod Kothari, Banking Law and Practice In India, 26

edition(Publication by Lexis Nexis),p-340.
} 
is also bound to use reasonable skill and diligence in his work otherwise, he will be liable for damges.

\section{Duty of bank to maintain secrecy}

Screcy is required in the matter of banker customer relationship. Account details of the customer cannot be disclosed to a third party.

Nobody can seek through a writ petition an enquiry into commercial transactions between the banker and customer. ${ }^{9}$

In the case of Kattabomman Transport Corporation Ltd. V. State Bank of India, it was that this is the duty of the banker towards the customer about the secrecrecy of the account. Such duty is the legal one duty which arises out of the contract made between them and not merely a moral one. ${ }^{10}$

\section{Termination of banker and customer Relationship}

\section{A. Termination by customer}

A customer at his own wish will at any time terminate the relationship with the bank closing his account in the foolowing reasons:

1. If the customer is dissatisfied with the services of the banker.

2. where banker is fail to provide the better services.

3. where customer feels that the bank is looses his reputation in the market and will effects its economic stability.

4. Where there is rumour about the winding up of wonding company.

5. when customernot agree with the terms of the banker.

\section{Termination by the Banker}

Undet the operation of Law

$>$ death of the customer.

$>$ Insanity of customer.

$>$ Insolvency of customer.

$>$ Assignmnet.

$>$ Order of the court.

$>$ Winding up of company.

$>$ Dissolution of partnership firm.

$>$ Customer of enemy character. ${ }^{11}$

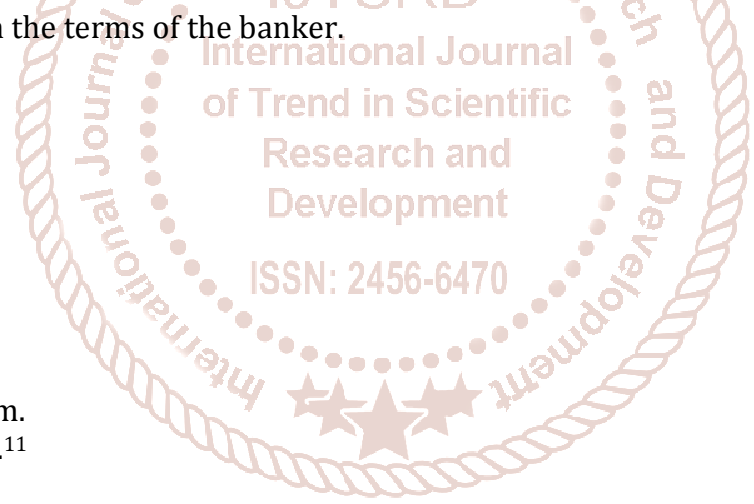

their job in that manner which will not detrimental/ prejudice to the right of other one.

\section{REFERENCE}

[1] Jyotsna Sethi and Nishwan Bhatia, Elements of Banking and Insurance,(Published by PHI Learning Pvt. Ltd. Delhi4.Reserve Bank of India.

[2] ICSI, Banking And Insurance Law And Practice, Published by Taxman.

[3] Kattabomman Transport Corporation Ltd. V. State Bank of India, AIR 1992 Ker 351.

[4] M L Tannan, Banking Law And Practice in India 23rd Edition, Published by Lexis Nexis, Nagpur.

[5] M L Tannan, Banking Law And Practice in India 21st Edition , Published by Lexis Nexis, Nagpur.

[6] R. N. Choudhary, Banking, Laws, central Law Publications, Allahabad.

[7] Reserve Bank of India.

[8] Vinod Kothari, Banking Law and Practice In India, 26 edition (Publication by Lexis Nexis).

\section{CONCLUSION}

From the above research, researcher reveals that about the meaning and nature of the relationship of customer and banker, from where it starts and what are the duities and obligations against each other to discharge their duty in respect of the contract they made with opening an account. Due to the various relationships after providing the different services to the customers by the bank. They both are bound to comply the terms and conditions settled between them, if any of the party will breach on the settled terms then it arises the problem of the termination of relation either by the customer or by the banker. It is suggested to that after breach by any of the party both the party vcan avail a legal remedy against each other by filling the complaint in the Consumer Protection Act, Banking Ombudsman scheme, Debt Recovery Tribunal, SARFAESI, Bankrupt and Insolvency Act. So in the last it's a duty cast upon both of them to do

\footnotetext{
${ }^{9}$ Ibid-9,p-331

${ }^{10}$ Kattabomman Transport Corporation Ltd. V. State Bank

of India , AIR 1992 Ker 351.

11 12. Ibid-2,p-135-137.
} 